\title{
Understanding Reservoir Operating Rules in the Transboundary Nile River Basin Using Macroscale Hydrologic Modeling with Satellite Measurements
}

\author{
HiSHAM ELDARDIRY AND FAISAL HOSSAIN \\ Department of Civil and Environmental Engineering, University of Washington, Seattle, Washington
}

(Manuscript received 9 March 2019, in final form 14 September 2019)

\begin{abstract}
Challenges to manage and secure a sustainable water supply are expected to become more acute in Egypt as the lowermost riparian country of the Nile basin with the construction of new transboundary water infrastructures in Ethiopia and Sudan. To understand the impact of such transboundary water projects on Egypt, it is first necessary to develop a modeling tool that can simulate potential flow and reservoir scenarios inside Egypt without requiring in situ hydrologic or transboundary dam data that are typically unavailable. This study presents the water management value of a modeling framework to predict the current and future reservoir operating rules in the lower Nile basin using satellite Earth observations and hydrologic models. The platform comprises the Variable Infiltration Capacity (VIC) hydrologic model driven by high spatial and temporal resolution of satellite observations. Reservoir storage change is estimated using altimeter and visible imagery of lake area for Lake Nasser and then applied to infer reservoir operation for High Aswan Dam (HAD). The modeling framework based on satellite observations yielded a simulated streamflow at the outlet for Blue Nile basin (BNB) with a Nash-Sutcliffe efficiency of 0.68 with a correlation and RMSE of 0.94 and $1095 \mathrm{~m}^{3} \mathrm{~s}^{-1}$, respectively. Storage and outflow discharge of HAD were estimated for the period of 1998-2002 within 1.4\% accuracy $\left(0.076 \mathrm{~km}^{3}\right.$ month $\left.^{-1}\right)$ when compared with published reports. Because BNB controls the lion's share of the variability to HAD inflow inside Egypt, the proposed modeling framework is appropriate for policy-makers to understand the implications of transboundary projects on the future water security of Egypt.
\end{abstract}

\section{Introduction}

The Nile River basin is home to more than 200 million people sharing the water resources for agriculture, industry, municipal uses, in-stream navigation, and hydropower generation. Maintaining a sustainable supply of water resources to meet these demands is a major water management issue for the Nile region due to increasing population, increasing water demand, recurring drought, and climate change. Nowhere is this issue more critical than in Egypt, the lowermost riparian country with a population of more than 90 million that is singularly dependent on the Nile River. In addition to a rapidly growing population, the agricultural sector in Egypt depends primarily on Nile water with a percentage of water withdrawal of $86 \%$ (FAO 2016). Such challenges to manage and secure sustainable water are expected to become more acute (for Egypt) with the construction of a new large-scale hydropower dam in Ethiopia known as Grand Ethiopian Renaissance Dam (GERD; Fig. 1).

\footnotetext{
Corresponding author: Faisal Hossain, fhossain@uw.edu
}

The GERD will be the key driver of flow regime change as the largest hydropower dam in Africa with over $60 \mathrm{~km}^{3}$ of active reservoir storage (e.g., 10 times the Grand Coulee Dam in the United States) and a 6000-MW hydropower capacity (King and Block 2014; Mulat and Moges 2014; Zhang et al. 2015).

In addition to the ongoing construction of the GERD dam, the future hydropower dams inventory provided by Zarfl et al. (2015) reveals an increasingly impounded Nile River for hydropower development upstream of Egypt. For instance, Fig. 1 shows three planned dams (Shereik, Kajbar, and Dal dams) in northern Sudan with a total hydropower capacity exceeding 2000 MW. If these dams become operational, the water availability for the three more powerful nations (Egypt, Sudan, and Ethiopia) will change dramatically. Hence, downstream countries (in this case it is only Egypt) need to understand what changes the upstream transboundary dams will bring to water security and Nile flow regime on seasonal and interannual time scales.

Egypt is the most downstream country that primarily relies on Nile water inflow as the main source of water 


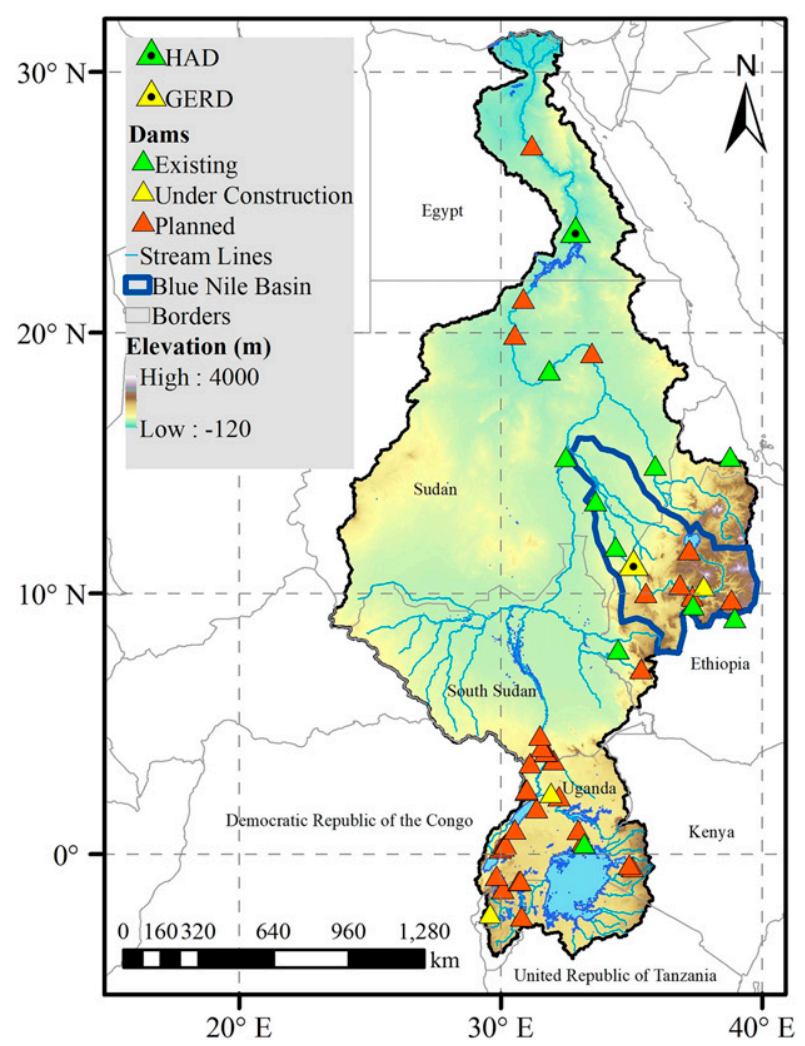

FIG. 1. Map of the Nile River basin with different stages of dams (existing, under construction, and planned) as provided by the GRanD Database (Lehner et al. 2011) and the global inventory of future hydropower dams (Zarfl et al. 2015).

supply with an annual average flow of $55.5 \mathrm{~km}^{3} \mathrm{yr}^{-1}$ under the Nile Waters Agreement of 1959 between Egypt and Sudan. Eighty-four percent of the water entering Egypt at Lake Nasser originates from the Ethiopian highlands through the Blue Nile basin (BNB) (57\%), Sobat River (14\%), and Atbara River (13\%) (Shahin 1985). At the peak flow season (July-October), the BNB provides nearly $70 \%$ of all water reaching High Aswan Dam (HAD) in Egypt, while the remaining 30\% is supplied by the White Nile and the Atbara River (Melesse et al. 2011; Taye et al. 2015). Alternative sources of water supply in Egypt include rainfall on the northern strip of the Mediterranean Sea and Sinai region, and groundwater (Allam and Allam 2007). The Nile River flow is almost fully controlled by the HAD once it enters Egypt. The HAD controls flow entering Lake Nasser to supply water required for irrigation and hydropower generation and to protect Egypt against floods in the Nile Delta (Abu-Zeid and El-Shibini 1997).

While GERD completion is expected to improve the energy and food security for Ethiopia, its impact on HAD operation and water security in Egypt is currently unknown. Adapting the current policies for
HAD operation (and without considering GERD), reported an expected water shortage of $26 \mathrm{~km}^{3} \mathrm{yr}^{-1}$ given population growth rate, expansion in industrial water withdrawals, and increase in agricultural areas. It is likely that a project like GERD will intensify such threats of water shortage and therefore result in reduced reliability for energy and food production in Egypt. Omar and Moussa (2016) proposed different planning measures to offset the expected shortage in water supply including, planning alternatives to the irrigation canals, controlling pumping rates of deep groundwater, and applying sprinkler and drip irrigation systems in new agricultural lands.

The current construction of the GERD dam along the BNB in Ethiopia will make the HAD operation rules face considerable uncertainty. The question now is, how should the reservoir rules be readjusted to cope with the expected reduction in inflow from the BNB due to an uncertain and closely guarded transboundary dam operation by GERD? Transboundary dams in developing nations most often do not share reservoir operating policy or storage plans with neighboring nations (Balthrop and Hossain 2010; Gerlak et al. 2011). Since a major concern is how the filling of the GERD reservoir will impact water availability in Egypt, it is important to understand current operation of HAD as an important first step. The use of hydrometeorological data is key information for understanding reservoir operation. However, such data are frequently not readily available, particularly in transboundary river basins, either because of lack of in situ measurements or due to lack of data sharing agreements among the riparian countries (Hossain et al. 2007; Plengsaeng et al. 2014). The limited ground-based observation network over the Nile River basin makes satellite products that are currently available at a wide range of spatial and temporal resolutions more appropriate.

The current study builds a modeling framework to understand the HAD reservoir operation using satellite observations. This satellite-based framework comprises two main components: 1) a macroscale hydrological model for the BNB; and 2) a satellite altimetry-based reservoir component combined with a hydrologic model to infer the operation of HAD reservoir. Satellite remote sensing has been shown to play a fundamental role in predicting the hydrologic state of the developing nations situated in international river basins (Hossain and Katiyar 2006). The use of such satellite-driven approach in modeling hydrologic conditions has been successfully implemented in operational environments for transboundary basins like the Mekong basin (Bonnema and Hossain 2017, 2019) and Ganges-Brahmaputra-Meghna (GBM) basin in Southeast Asia (Siddique-E-Akbor et al. 
2014) and the Indus River basin (Iqbal et al. 2016, 2017). Over the Nile River basin, satellite observations have been applied for many applications, such as rainfall estimation (e.g., Dinku et al. 2011; Rientjes et al. 2011; Habib et al. 2012; Gebremichael et al. 2014), evapotranspiration modeling (e.g., Enku et al. 2011; Allam et al. 2016) and monitoring water storage using Gravity Recovery and Climate Experiment (GRACE) satellites (e.g., Longuevergne et al. 2013; Awange et al. 2014). Our study builds on the current availability of satellite-based observations of various water cycle variables, terrain, and land cover at high temporal and spatial resolutions to set up a macroscale hydrological model for the BNB. Our first objective is to implement the Variable Infiltration Capacity (VIC) macroscale model for the BNB to develop the first component of the satellitebased framework.

The second objective of our study is to understand the reservoir operation for Lake Nasser impounded by the HAD. The introduction of satellite remote sensing provides a pragmatic way forward to monitor reservoir dynamics through imagery or data from various freely available satellite sensors such as Landsat and MODIS sensors (Wulder et al. 2012). Measuring water level fluctuations in reservoirs is now well-established using satellite altimetry (Birkett 1998; Alsdorf et al. 2001; Calmant et al. 2008). For example, Keys and Scott (2018) used MODIS images and altimetry data over Lake Tana to estimate surface area and water level, respectively. They found that in situ data and satellite-based estimation for surface area and water level are in a high level of agreement with correlation coefficient of 0.88 and 0.97 , respectively. In our study, the outputs from the hydrological model (mainly the routed streamflow) are combined with altimetry-based water levels and SRTM data to estimate the outflow from the HAD reservoir using a water balance approach. A similar approach has been applied by Bonnema and Hossain (2017) in the Mekong River and by Bonnema et al. (2016) in the Karnaphulli River. They reported the feasibility of satellite driven models in capturing the spatiotemporal variability of reservoir dynamics in terms of outflows and storage change. Given the limited data shared between Nile riparian countries, building a predictive framework based on the satellite information is fundamentally the only pathway toward understanding the impacts of ongoing and future transboundary water projects on surface water availability.

A central question addressed by our study is can we benefit from satellite hydrometeorological observations and hydrologic modeling to build a skillful predictive framework that can efficiently reproduce the operation of the HAD? Building such satellite-based framework will contribute to the existing class of models available for the Nile basin, that have been primarily driven by in situ data and requires retrieving such data from local water resource agencies in near-real time. RIBASIM (van der Krogt and Ogink 2013) and RiverWare (Wheeler and Setzer 2012) are two examples of hydrologic models which were developed as part of Eastern Nile Planning Models project in the Eastern Nile Technical Regional Office (ENTRO) of Nile Basin Initiative (NBI). While the in situ data for such models were made available by the ENTRO office, our satellite framework has the benefit of using globally free satellite images to understand reservoir operation independent of availability of in situ data from multiple agencies. Furthermore, our predictive framework is intended to lay the background for subsequent investigation of the impacts of future water projects on the management of water resources in eastern Nile basin riparian countries (Ethiopia, Sudan, and Egypt). Examples of such investigations include 1) studying the impacts of GERD (during filling and operation phases) on the water reaching Sudan and Egypt and 2) revisiting the HAD operation rules to account for water flow changes induced by upstream projects. The remainder of the paper is organized as follows: we introduce the study area in section 2, data sources and methods are summarized in section 3, results for the hydrological modeling and monitoring HAD reservoir operation are discussed in section 4 , and implications of the developed framework and concluding remarks are in section 5 .

\section{Study area}

The Nile River basin is a major transboundary river that passes through 11 countries in northeastern Africa (Fig. 1): Burundi, Egypt, Eritrea, Ethiopia, Kenya, Rwanda, Sudan, South Sudan, Tanzania, Uganda, and the Democratic Republic of the Congo (DRC). It comprises two major tributaries, the Blue Nile basin and the White Nile. The White Nile originates from the Great Lakes region of central Africa, and flows north through Tanzania, Lake Victoria, Uganda, and southern Sudan. The Blue Nile starts at Lake Tana in Ethiopia and is considered the primary tributary of the main Nile River (given its high contribution to total Nile River discharge). The confluence of the Blue Nile and the White Nile is at the Sudanese capital Khartoum. The river then flows north through Sudan and Egypt to drain into the Mediterranean Sea. Precipitation within the basin is highly seasonal, driven primarily by the northward and southward movement of the intertropical convergence zone (ITCZ) and other large-scale oceanicatmospheric drivers (Block and Rajagopalan 2007). 
Annual precipitation rates in the Ethiopian highlands range from 800 to $2200 \mathrm{~mm}$, with the majority falling during the main rainy season [from June to September (JJAS)] (Melesse et al. 2011).

The water management in the Nile River is challenging due to increasing population, climate change, and future plans on building new dams. Figure 1 shows the existing, planned, and under construction dams in the basin according to the Global Reservoir and Dam (GRanD) Database (Lehner et al. 2011) and the global inventory of hydropower dams produced by Zarfl et al. (2015). The major dams on the Nile are Roseires Dam (situated in BNB in Sudan), Sennar Dam (situated in BNB in Sudan), Merowe Dam (the main Nile in Sudan), High Aswan Dam (the main Nile in Egypt), and Owen Falls Dam (White Nile at Lake Victoria in Uganda). The purposes of the major dams are to produce hydroelectric power and provide water supply needed to meet irrigation demands. The most downstream dam is the HAD dam that was built to provide hydropower (2100 MW) and regulate the water releases for irrigation demands in the Nile Delta.

The HAD storage reservoir is Lake Nasser, which is one of the largest man-made lakes in the world and is key to Egypt's water security. The lake has a length of about $500 \mathrm{~km}$ and it is located in a very dry climate with an average annual evaporation of $2.1 \mathrm{~m} \mathrm{yr}^{-1}$ (about $8 \%$ of the average reservoir depth) and negligible rainfall (Ebaid and Ismail 2010). The operation rule of Lake Nasser reservoir is paramount to ensuring adequate water supply and the safety of the HAD. At the beginning of the water year (1 August), the water level is kept at $175 \mathrm{~m}$ above mean sea level (MSL) to fulfill high and low flow requirements (Muala et al. 2014). When the water level upstream exceeds $178 \mathrm{~m}$, water is redirected to the Toshka Depression and, if necessary, sluices or emergency spillways are used to release the surplus flow (Bastawesy et al. 2008). The maximum retention at $180 \mathrm{~m}$ MSL is obtained in November. As water is released from January to July, the reservoir levels decrease (El-Shafie et al. 2007). The regulation of the HAD reservoir and releases to fulfill downstream irrigation in Egypt have been decided on by the 1959 treaty between Egypt and Sudan (Waterbury 2008; Awulachew et al. 2011). This treaty, entitled "The Full Utilization of the Nile," allocated all the Nile flow between the two countries $\left(55.5 \mathrm{~km}^{3}\right.$ for Egypt and $18.5 \mathrm{~km}^{3}$ for Sudan) with no consideration of upstream riparian countries and their development plans. However, such situation is currently changing with ongoing development projects in the BNB (e.g., GERD dam) and hence, it becomes of utmost importance to reevaluate the operation of the HAD dam.

\section{Datasets and methods}

\section{a. Macroscale hydrologic model}

As mentioned earlier, the first objective of our study is to build and demonstrate the predictive skill of a hydrological modeling framework for the BNB that can be used to assess reservoir operations in the Nile River. We used the VIC model. VIC is a macroscale hydrological model that represents surface and subsurface hydrologic processes on spatially distributed grid cells (Liang et al. 1994, 1996). The model parameterization includes the representation of subgrid-scale variability in vegetation coverage, topography, precipitation, and soil moisture storage capacity. The VIC model has been successfully used for a large number of hydrological studies in different climatic environments (see, e.g., Lohmann et al. 1998; Nijssen et al. 2001; Maurer et al. 2002; Liang and Guo 2003; Zhu and Lettenmaier 2007).

In our study, the VIC model was implemented at $0.1^{\circ}$ $(\sim 10 \mathrm{~km})$ spatial resolution for the BNB and using the water balance approach for each grid cell. Table 1 summarizes the types of data that are processed and analyzed for setting the BNB VIC model:1) topographic data, 2) meteorological forcing data, 3) vegetation data, and 4) soil data. The VIC model primary forcing for running water balance mode are precipitation, maximum and minimum temperature, and daily average wind speed. The daily satellite-based precipitation was retrieved from the latest version of the Climate Hazards Infrared Precipitation with Stations (CHIRPS v.2) dataset for the 37-yr period of 1981-2017 (Funk et al. 2014, 2015). CHIRPS has been globally used as a useful rainfall dataset for trend analysis and seasonal drought monitoring (e.g., Bayissa et al. 2017; Paredes-Trejo et al. 2017; Gao et al. 2018), given its long time series record (more than 30 years) and high spatial resolution $\left(0.05^{\circ}\right)$. For example, Bayissa et al. (2017) selected the CHIRPS rainfall product, due to its higher accuracy compared to other satellite-based precipitation estimates (e.g., PERSIANN and TRMM products), to assess the spatial and temporal variability of meteorological drought for the upper BNB. They concluded that CHIRPS rainfall product can be used for developing grid-based drought monitoring tools for the basin. Daily temperature (minimum and maximum) and wind speed data were obtained from the Global Summary of the Day by the National Climatic Data Center (GSOD/NCDC).

A digital elevation model (DEM) was created for the BNB by collecting elevation data from the Shuttle Radar Topographic Model (SRTM). The SRTM data were used to determine the stream network (flow direction data) in the BNB. Vegetation data such as 
TABLE 1. Summary of the datasets used as inputs in the VIC modeling of the BNB.

\begin{tabular}{llc}
\hline \hline \multicolumn{1}{c}{ Input } & \multicolumn{1}{c}{ Dataset } & Spatial resolution \\
\hline Precipitation & Climate Hazards Infrared Precipitation with Stations (CHIRPS) & $0.05^{\circ}$ \\
Temperature & National Climatic Data Center (NCDC) & Gauges \\
Wind speed & National Climatic Data Center (NCDC) & Gauges \\
Topography & Shuttle Radar Topographic Model (SRTM) & $30 \mathrm{~m}$ \\
Soil type & Harmonized World Soil Database (HWSD) & 30 arc s \\
Land cover & Global Land Cover Characterization (GLCC) & $1 \mathrm{~km}$ \\
Vegetation type & Moderate Resolution Imaging Spectroradiometer (MODIS) & $500 \mathrm{~m}$ \\
\hline
\end{tabular}

monthly leaf area index and albedo were obtained from the Moderate Resolution Imaging Spectroradiometer (MODIS) mission. The MODIS data have been widely used to classify vegetation type over many river basins [see, e.g., Teferi et al. (2015) and Allam et al. (2016) over the upper BNB]. Land cover type was prepared using the Global Land Cover Characterization (GLCC; Loveland et al. 2000), while soil type data were obtained from the Harmonized World Soil Database (HWSD; Nachtergaele 1999).

The aforementioned forcing datasets were processed over the BNB at a daily scale and regridded to the $0.1^{\circ}$ spatial scale to drive the VIC model land surface simulations. The runoff (from the VIC outputs) over each grid cell was then routed separately using the routing model scheme of Lohmann et al. (1998). We calibrated the BNB model for daily and monthly streamflow at Khartoum station (outlet of the BNB) (Fig. 1). The calibration and validation procedures were performed over 5-yr periods of 1993-97 and 1998-2002, respectively, during which streamflow observations are available. In situ data were obtained for calibration and validation periods from reports published by the Ministry of Water Resources and Irrigation (MWRI) in Egypt. In addition to visual comparison of monthly simulated and observed hydrographs, error statistics were used to assess the model performance. These metrics are relative bias (RBIAS), root-mean-square error (RMSE), normalized root-mean-square error (NRMSE), correlation coefficient, and Nash-Sutcliffe model efficiency coefficient (NSE).

\section{b. Reservoir modeling approach}

The reservoir modeling approach was built on the VIC modeling framework. Dam operating rules for Lake Nasser reservoir were inferred by calculating outflow discharges of HAD using a water balance approach. Figure 2 shows a schematic diagram for the different tributaries contributing to the inflow at HAD. Figure 3 shows the monthly streamflow along the tributaries feeding the Main Nile (Blue Nile, White Nile, and Atabara River). Because BNB represents the lion's share of the total flow in the main Nile in
Egypt, the variability of the inflow to Lake Nasser can be assumed to be primarily controlled by the BNB flow. Average monthly flow contributing from the White Nile and Atbara rivers were retrieved from Sutcliffe and Parks (1999) at the two outlet stations: Mogren and Atbara, respectively. The estimation of reservoir releases was then computed through a three-step process as follows.

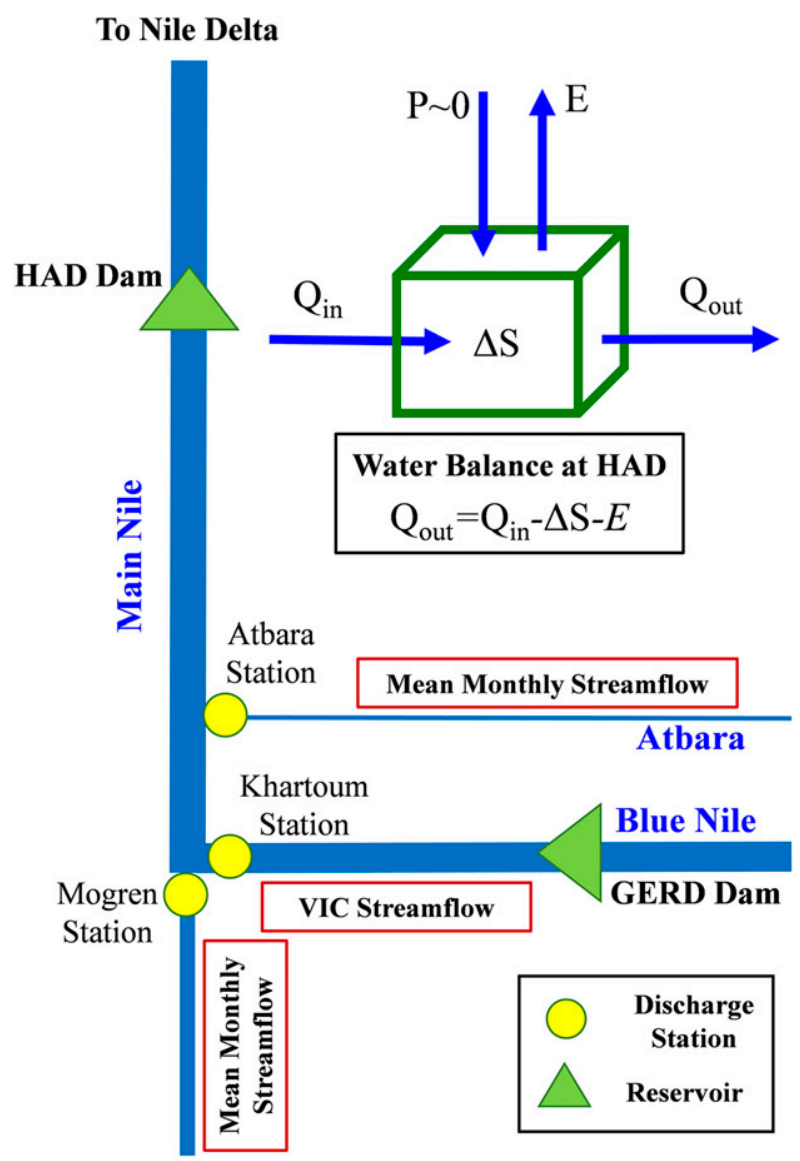

White Nile

FIG. 2. Schematic diagram of the streamflow from the Nile River tributaries that contribute to the total flow reaching the HAD in Egypt. The yellow dots represent the stations at the outlet of the White Nile (Mogren), Blue Nile (Khartoum), and Atbara River (Atbara). 


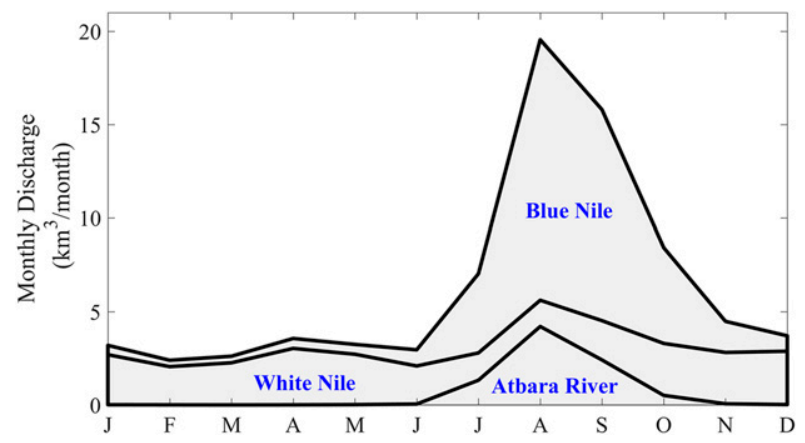

FIG. 3. The contribution of Blue Nile, White Nile, and Atbara River tributaries to the monthly streamflow of the main Nile [data source: Sutcliffe and Parks (1999)].

\section{1) Deriving AREA-ELEVATION CURVE}

A relationship between reservoir surface area and elevation was established for the reservoir under study (Lake Nasser in our case). This relationship is known as the area-elevation curve. For Lake Nasser, a 30-m resolution DEM provided by SRTM was classified into 1-m elevation bands over the reservoir and surrounding area. The surface area of each elevation band provides an estimate of the reservoir surface corresponding to the water elevation reached. Deriving area-elevation curves using satellite-based estimates has been widely employed in previous studies [see, e.g., Wang et al. (2013) over the Three Gorges reservoir and Bonnema and Hossain (2017) over the Mekong River]. To infer water elevation below the level when SRTM overpassed the HAD reservoir, additional observations of water surface area from Landsat images were used. The classification of the Landsat image was performed using the normalized difference water index (NDWI) using the reflectance values in the green and nearinfrared wavelengths, respectively (for more details, see Bonnema and Hossain 2017). Figure 4 shows the derived relationship between water surface elevation and surface area over Lake Nasser.

\section{2) Altimetry-BASed WATER LeVels}

The derived area-elevation curve was used to convert satellite measurements of water surface elevation into reservoir volume. The water levels over Lake Nasser were estimated using the radar altimetry-based water surface elevations that were acquired from the operational satellite altimetry Hydroweb database. This database involved five radar altimetry missions including T/P (TOPEX/Poseidon), Jason-1, Jason-2, Geosat Follow-On ( GFO), and Environmental Satellite (Envisat). The reader is referred to Crétaux et al. (2011) for a detailed description of the procedures used for processing water level in Hydroweb. To validate our

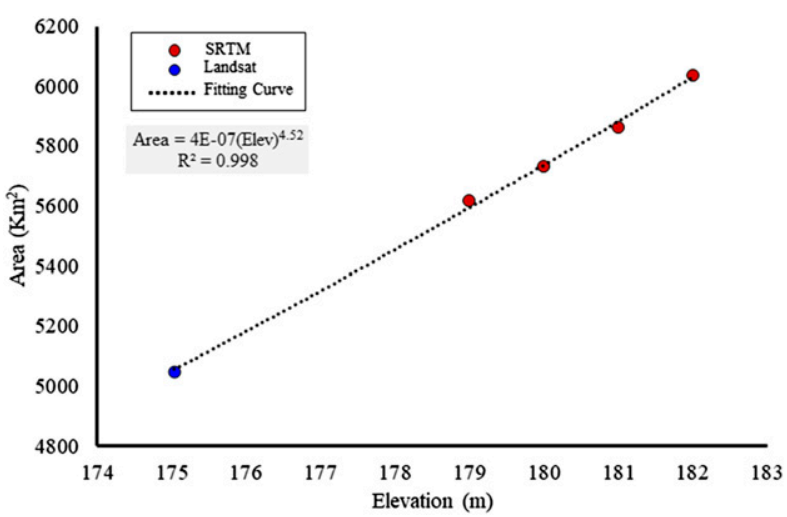

FIG. 4. Deriving elevation-area curve for the HAD using SRTM (the lowest point is derived from Landsat images and the corresponding altimetry-based water level).

results, in situ water levels from a gauging station upstream of HAD were compared with satellite derived estimates. Figure 5 shows the altimetry water level for the period 1998-2002 in good agreement with observed water levels in terms of phase and amplitude. Correlation coefficient and RMSE of monthly data from Hydroweb against in situ water levels are 0.99 and $0.40 \mathrm{~m}$, respectively. The RMSE represents about $0.22 \%$ of the mean monthly water level $\sim 178.49 \mathrm{~m}$. Such metrics indicate very close agreement with measured levels and the skill of altimetry-based water levels for our water balance modeling. The Hydroweb was chosen over other preprocessed datasets because of its accuracy over Lake Nasser reservoir. For example, we observed that the mean absolute error of water level over Lake Nasser from the Hydroweb dataset was $0.3 \mathrm{~m}$ compared to $0.7 \mathrm{~m}$ using the USDA Global Reservoir and Lake Monitoring (GRLM) database.

\section{3) WATER BALANCE MODEL}

A water balance model [Eq. (1)] was used to compute the reservoir release, which was then applied to establish a monthly release curve for the HAD reservoir. The water balance equation (assuming negligible groundwater interactions) is

$$
Q_{\text {out }}=Q_{\text {in }}-\frac{d S}{d t}-E,
$$

where $Q_{\text {in }}$ is the inflow $\left(\mathrm{km}^{3}\right.$ month $\left.^{-1}\right), Q_{\text {out }}$ is the reservoir discharge downstream of the HAD $\left(\mathrm{km}^{3}\right.$ month $\left.^{-1}\right)$, $E$ is the open water evaporation $\left(\mathrm{km}^{3}\right.$ month $\left.^{-1}\right)$, and $d S / d t$ represents the change in storage volume with time $\left(\mathrm{km}^{3}\right.$ month $\left.^{-1}\right)$. The monthly inflow to the reservoir $Q_{\text {in }}$ was obtained from routing of the VIC modeled runoff at Khartoum station and adding the average monthly flow from the White Nile and Atbara River (see the schematic 


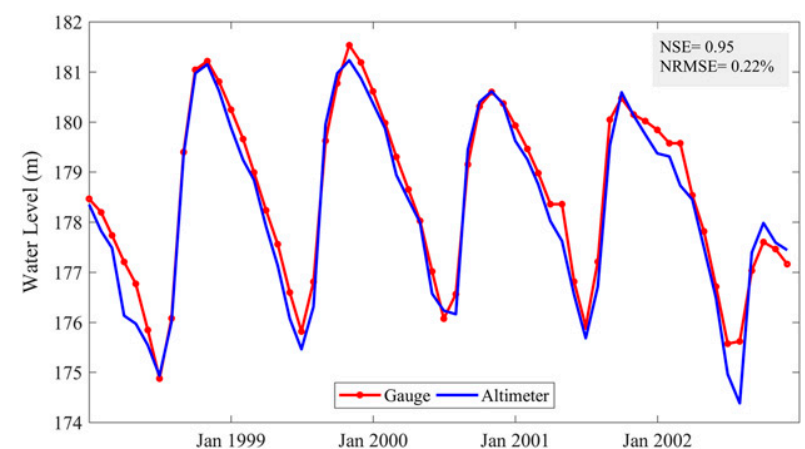

FIG. 5. Altimetry-based water levels compared to gauge readings over Lake Nasser.

diagram in Fig. 2). Considering only the Blue Nile variability in the streamflow reaching HAD is justified by the larger share of discharge from the BNB compared to the Atbara River and the White Nile (Fig. 3). In addition, we compared the variability introduced by the three rivers (Blue Nile, White Nile, and Atbara River) to the flow in the main Nile using the range of monthly discharge at the outlet of each river standardized by the mean monthly discharge upstream of HAD (range is calculated as the difference between the maximum and minimum monthly streamflow retrieved from gauges at the outlet of each river). We found that the variability from the Blue Nile is much higher than that introduced by the White Nile and Atbara River, especially during the rainy season (JJAS), when the variability is more than $100 \%$ of the mean flow in the main Nile (figure not shown). The evaporation losses $E$ were estimated using the standard energy balance method as described by Chow et al. (1988). Minimum and maximum temperature required for the energy balance method were obtained from the GSOD/NCDC dataset. Two constraints were added in the water balance model to control the HAD releases. First, the inflow to the HAD is reduced by a factor of $25 \%$ which corresponds to the average Sudan share of the Main Nile flow (18.5 out of $84 \mathrm{~km}^{3} \mathrm{yr}^{-1}$ ) according to the 1959 Nile Waters Agreement (Waterbury 2008). Second, the maximum HAD release is set to $8.1 \mathrm{~km}^{3}$ month ${ }^{-1}$ in order to maintain the water level in the HAD reservoir below $178 \mathrm{~m}$. As noted earlier in section 2, any excess discharge above $178 \mathrm{~m}$ is always spilled into the Toshka depression in the western desert of Egypt.

\section{Results and discussion}

\section{a. Model calibration and validation}

As described in section $3 b$, the VIC model for the $\mathrm{BNB}$ is forced by CHIRPS precipitation estimates, while temperature and wind speed are provided by NCDC gauges. We calibrated the soil parameters of VIC model to reflect hydrological response and adjust the runoff generation accordingly. Table 2 summarizes the soil parameters calibrated to simulate the streamflow at Khartoum station (outlet of the BNB). Figure 6 shows the daily and monthly time series of simulated streamflow and compared with measured discharge at Khartoum station. Figures $6 \mathrm{a}$ and $6 \mathrm{~b}$ show high correlation between the modeled and measured streamflow at daily and monthly time scales. The correlation coefficient and NSE for daily (and monthly) streamflow are $0.85(0.49)$ and $0.94(0.68)$, respectively (Table 3 ). The model simulations show also better fit with monthly flows as indicated by lower values of RBIAS and RMSE (e.g., $751 \mathrm{~m}^{3} \mathrm{~s}^{-1}$ for monthly streamflow of the calibration period 1993-97 compared to $1280 \mathrm{~m}^{3} \mathrm{~s}^{-1}$ from daily simulations for the same period). In general, the VIC simulations reproduced the observed long-term monthly mean hydrograph and also captured interannual and intra-annual flow variations. The skillful predictability of the VIC model at the Khartoum station is confirmed during the validation period of 1998-2002 where a correlation coefficient of 0.96 between monthly simulated and measured streamflow is observed.

Furthermore, we tested the model performance for the Blue Nile upstream of Eldiem station, where the GERD is currently being constructed. The ability of the model to simulate the flow upstream of Eldiem station is critical to the success of the modeling framework in exploring future impacts of planned dams in the BNB (e.g., GERD dam). Monthly simulated streamflow was compared with discharge at Eldiem station for the calibration (1993-97) and validation (1998-2002) periods. The simulated flow showed an overestimation in three years $(1993,1995$, and 1997) of the calibration period at the peak flows (in August) (Fig. 7a). Conversely, streamflow was underestimated at peak flows of the five validation years with an average absolute bias of $889 \mathrm{~m}^{3} \mathrm{~s}^{-1}$ (compared to $1226 \mathrm{~m}^{3} \mathrm{~s}^{-1}$ for the calibration period) (Fig. 7b). However, the model generally showed a close agreement between the simulated and observed monthly streamflow with a NSE and correlation coefficient of 0.92 and 0.97 , respectively during the validation period $(\mathrm{NSE}=0.81$ and correlation coefficient $=0.93$ for the calibration period). According to the watershed modeling evaluation guidelines established by Moriasi et al. (2007), hydrological modeling of streamflow with such NSE greater than 0.50 is considered to be very satisfactory for simulating streamflow at a monthly time step. Overall, the performance results of the calibrated VIC model are reasonable for our proposed investigations, especially 
TABLE 2. Soil parameters calibrated for VIC modeling of the BNB.

\begin{tabular}{|c|c|c|c|c|}
\hline \multirow[b]{2}{*}{ Parameter } & \multirow[b]{2}{*}{ Definition } & \multirow[b]{2}{*}{ Typical range } & \multicolumn{2}{|c|}{ Calibrated value for the $\mathrm{BNB}$} \\
\hline & & & $\begin{array}{c}\text { Upstream } \\
\text { Eldiem station }\end{array}$ & $\begin{array}{l}\text { Downstream } \\
\text { Eldiem station }\end{array}$ \\
\hline binf & Shape parameter of the infiltration curve & $>0-0.4$ & 0.2 & 0.01 \\
\hline$d$ & Soil depth & $>0.1-1.5$ & 0.7 & 1.3 \\
\hline Ds & The fraction of maximum velocity of baseflow & $>0-1$ & 0.1 & 0.002 \\
\hline Ws & The fraction of the maximum soil moisture & $>0-1$ & 0.9 & 0.9 \\
\hline
\end{tabular}

with its skill in capturing the peak and variability of the streamflow.

\section{b. Hydrologic characterization of the Blue Nile}

The BNB modeling framework developed in our study was used to understand long-term trends and climatology of various hydrologic variables in the BNB including precipitation, evaporation, runoff, and streamflow. Such hydrologic characterization is essential for future investigations of new dams operating policy, which consequently impacts the downstream water structures. For instance, it is important to demonstrate the predictability of our VIC model in characterizing the evaporation over the BNB (especially at GERD location). Evaporation at GERD impounding lake is a key variable in subsequent studies that consider GERD impacts, given the claims by the Ethiopian side that GERD will increase the water flows downstream by reducing evaporation from Lake Nasser (Yihdego et al. 2017; Taye et al. 2016). Additionally, we provided a characterization of the streamflow
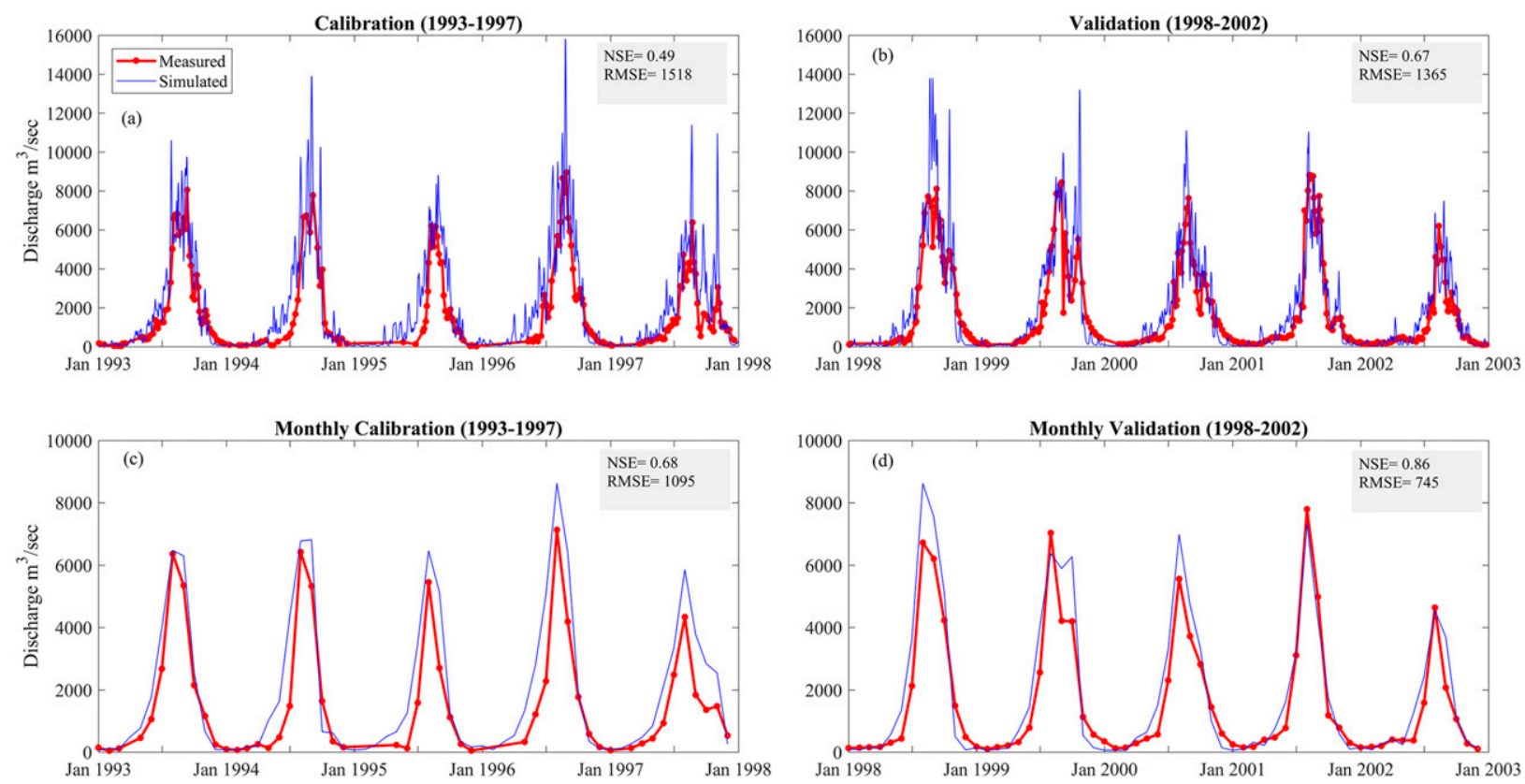

FIG. 6. (left) Model calibration and (right) validation for the BNB at Khartoum Station for the periods 1993-97 and 1998-2002, respectively. The model performance assessment at (a),(b) daily and (c),(d) monthly scales is shown using the NSE coefficient and RMSE. 
TABLE 3. Performance statistics for the calibration and validation of the streamflow at Khartoum and Eldiem stations.

\begin{tabular}{|c|c|c|c|c|c|c|}
\hline Station & Simulation & NSE & Correlation coefficient & RBIAS & $\operatorname{RMSE}\left(\mathrm{m}^{3} \mathrm{~s}^{-1}\right)$ & NRMSE \\
\hline & \multicolumn{6}{|c|}{ Calibration (1993-97) } \\
\hline \multirow[t]{2}{*}{ Khartoum } & Daily & 0.49 & 0.85 & $37 \%$ & 1518 & $78 \%$ \\
\hline & Monthly & 0.68 & 0.94 & $43 \%$ & 1095 & $69 \%$ \\
\hline \multirow[t]{2}{*}{ Eldiem } & Monthly & 0.81 & 0.93 & $3 \%$ & 772 & $50 \%$ \\
\hline & \multicolumn{6}{|c|}{ Validation (1998-2002) } \\
\hline \multirow[t]{2}{*}{ Khartoum } & Daily & 0.67 & 0.88 & $17 \%$ & 1365 & $68 \%$ \\
\hline & Monthly & 0.86 & 0.96 & $18 \%$ & 745 & $47 \%$ \\
\hline Eldiem & Monthly & 0.92 & 0.97 & $-11 \%$ & 540 & $31 \%$ \\
\hline
\end{tabular}

error bars in Fig. 9, the interannual variability in precipitation is relatively high for the transition months, with October having the highest standard deviation of $23 \mathrm{~mm}$. Figure $8 \mathrm{~b}$ shows the spatial variation of evaporation rates over the entire BNB. This was calculated by summing the canopy evaporation, transpiration, and bare soil evaporation from the VIC model and then averaged over each grid cell. Higher evaporation rates are seen in upstream regions of the BNB with an average monthly evaporation of $82 \mathrm{~mm}$. The overall characterization of the hydrologic variables from the BNB VIC modeling are in close agreement with previous studies that described the BNB hydrology (e.g., Melesse et al. 2011; Elshamy et al. 2009).

Figure 10a shows the cumulative distribution of the annual streamflow at Eldiem station, that is, inflow to GERD dam. The median annual streamflow is about $47.5 \mathrm{~km}^{3} \mathrm{yr}^{-1}$, which represents about two third of the expected storage in the GERD reservoir $\left(74 \mathrm{~km}^{3}\right)$. The interannual and intra-annual variability of the streamflow are indicated by the interquartile range of the box plot and the month by month changes shown in Fig. 10b. Higher streamflow is produced during the wet season months (JJAS) where heavier precipitation falls on the upper Blue Nile basin. Examples of wet years with the highest monthly streamflow at Eldiem station are
September $1993\left(21.7 \mathrm{~km}^{3}\right.$ month $\left.^{-1}\right)$ and August 2011 $\left(20 \mathrm{~km}^{3}\right.$ month $\left.^{-1}\right)$. The streamflow at Eldiem station lags rainfall by about one month with peak discharge in August. The average monthly discharge in August (for the 1981-2017 period) is $13.4 \mathrm{~km}^{3}$ month $^{-1}$ with interquartile range of $3 \mathrm{~km}^{3}$ month $^{-1}$. The highest intraannual variability of streamflow is observed in September with interquartile range of $3.9 \mathrm{~km}^{3}$ month $^{-1}$. Such variability in the streamflow reaching Eldiem station is controlled by the effect of timing and sequence of El Niño and La Niña in the upper BNB. For instance, Zaroug et al. (2014) found that $80 \%$ of the drought cases in the upper BNB are associated with El Niño events. The predictive skill of the VIC model to characterize the streamflow climatology upstream of the GERD is crucial for exploring impacts on water management downstream of the eastern (Blue) Nile region.

\section{c. Water balance of $H A D$ reservoir}

The outflow discharges of High Aswan Dam were computed following the water balance described in section $3 b(3)$. Figure 11a shows the comparison of the outflow using the water balance model based on altimetry satellite water levels and the measured discharge at the HAD sluice gates. The modeled outflows show
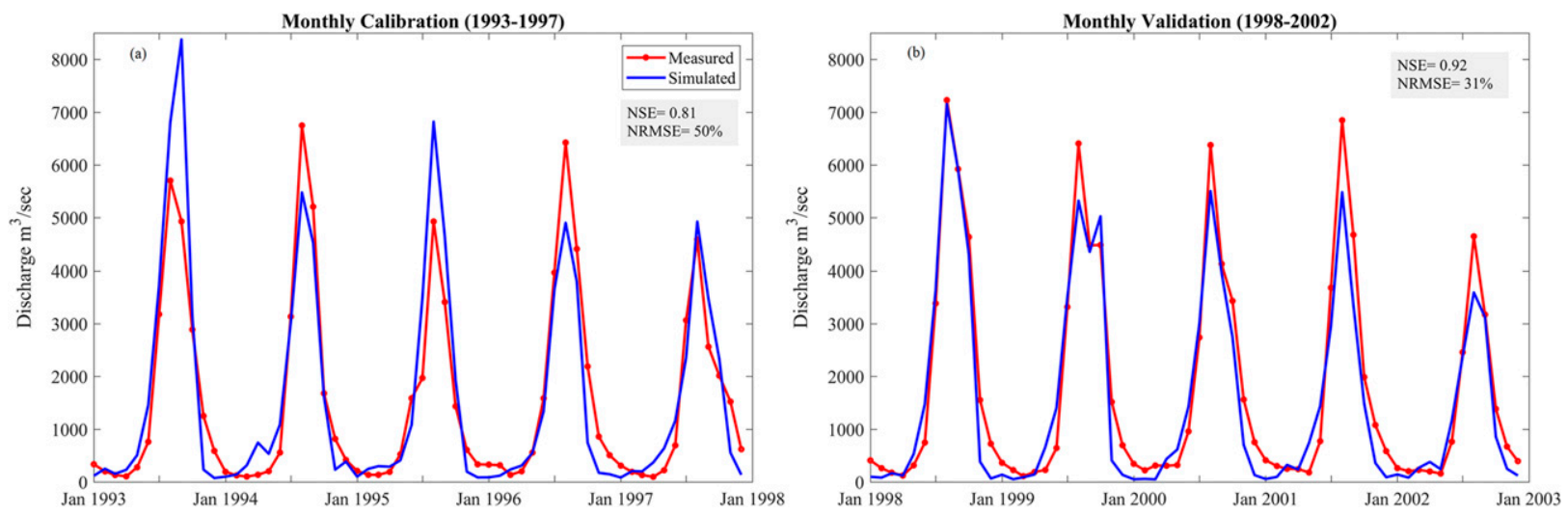

FIG. 7. Model calibration and validation of monthly streamflow at Eldiem station (the location of the GERD dam at the boundary between Ethiopia and Sudan) for the periods 1993-97 and 1998-2002, respectively. 
(a) Precipitation $(\mathrm{mm} / \mathrm{day})$

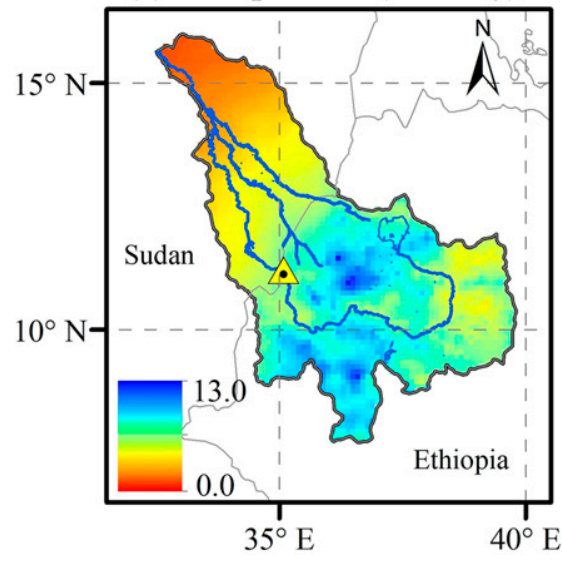

(b) Evaporation ( $\mathrm{mm} / \mathrm{day})$

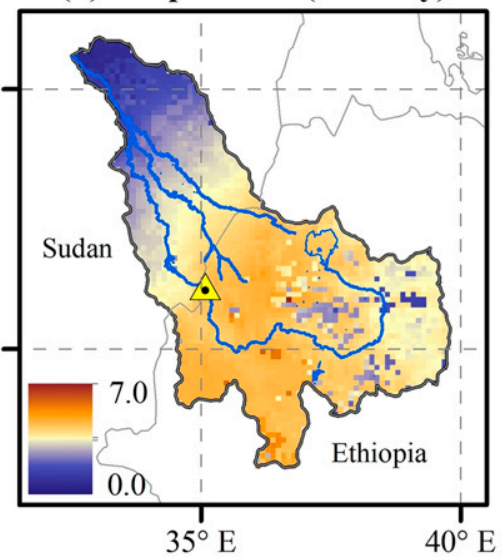

(c) Runoff (mm/day)

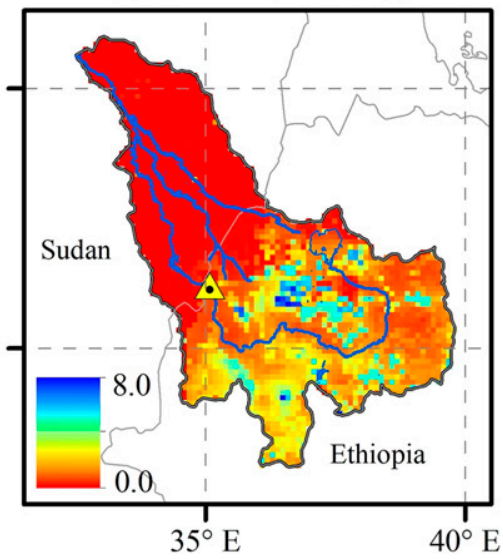

FIG. 8. Average daily climatology of (a) precipitation, (b) evaporation, and (c) runoff for the BNB in the JJAS season over the period of analysis (1981-2017). The yellow triangle represents the location of the GERD dam (Eldiem station) at the boundary between Ethiopia and Sudan.

higher variations between the monthly discharges with some spikes of overestimation especially in the dry season. However, there is good agreement between the streamflow at months of peak flow. The water balance model resulted in a NSE of 0.20 and a correlation coefficient of 0.67 . Figure $11 \mathrm{~b}$ shows the HAD operating curve for each month (averaged over the period 19982002) as compared to the measured releases. The water balance approach captures the overall HAD operating curve with higher releases in the summer season compared to the rest of the year. The simulated HAD releases match more closely with measured discharge during summer (June-August), with less than 10\% NRMSE (Table 4) and slight overestimation (relative bias $=7 \%$ ). Conversely, the performance of the simulated HAD outflow is less accurate for the fall season (SeptemberNovember) with considerable underestimation in the reservoir releases (relative bias $=27 \%$ and NRMSE $=$ $47 \%$ ). This trend can be also seen in the hydrograph in Fig. 11b.

The differences between observed and modeled streamflow may be due to several sources of uncertainties in the water balance equation. The inflow simulated by the VIC model, for example, is one factor that affects the inflow term of the water balance equation. For instance, the water balance performance is lower in years impacted by the differences between the measured discharge and the streamflow simulated by the VIC model at Khartoum station (e.g., the simulated peak discharge in 1998 and 2000 are overestimated compared to the measured discharge; Fig. 6d). When only considering the year 2002, which has very comparable simulated and measured discharge, the performance of the reservoir model was significantly improved with higher
NSE (0.87) and correlation coefficient (0.94) (see dashed lines in Fig. 11b). In addition, tracking down some points (having larger magnitude of error) in the HAD outflow curve, we found that overestimation or underestimation of altimetry water levels can impact significantly the water balance equation. For example, one meter of overestimation in altimetry water level in April 1998 resulted in higher HAD simulated outflow $\left(8.1 \mathrm{~km}^{3}\right.$ compared to only $4.5 \mathrm{~km}^{3}$ measured downstream of the HAD). Testing the sensitivity of the water balance approach to the HAD inflow and the water level (figure not shown), we noticed that improvement in NSE is more sensitive to the water level estimates (NSE increased from 0.20 to 0.36 when using measured water level at HAD reservoir, while keeping the other components of the water balance equation the same). Furthermore, as indicated by Muala et al. (2014), the large

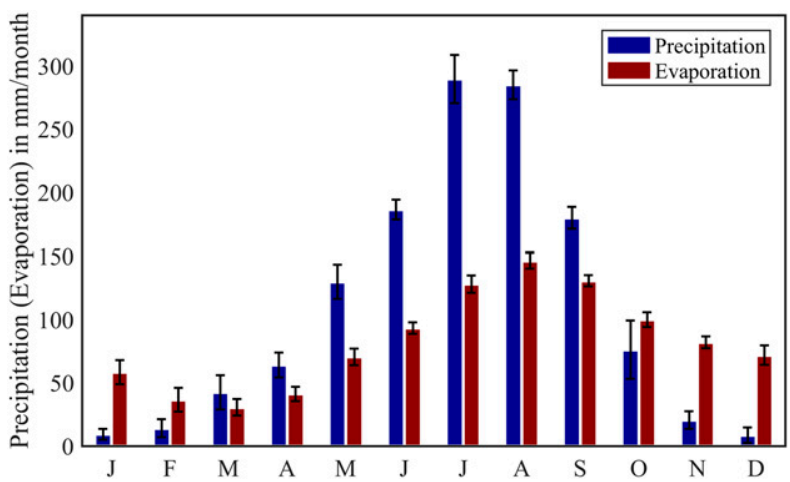

FIG. 9. Average monthly precipitation (from CHIPRS; $\mathrm{mm}$ month $^{-1}$ ) and evaporation (from VIC output; $\mathrm{mm}$ month ${ }^{-1}$ ) over the upper BNB basin (upstream Eldiem station) during the period 1981-2017 (error bars indicate the standard deviation). 

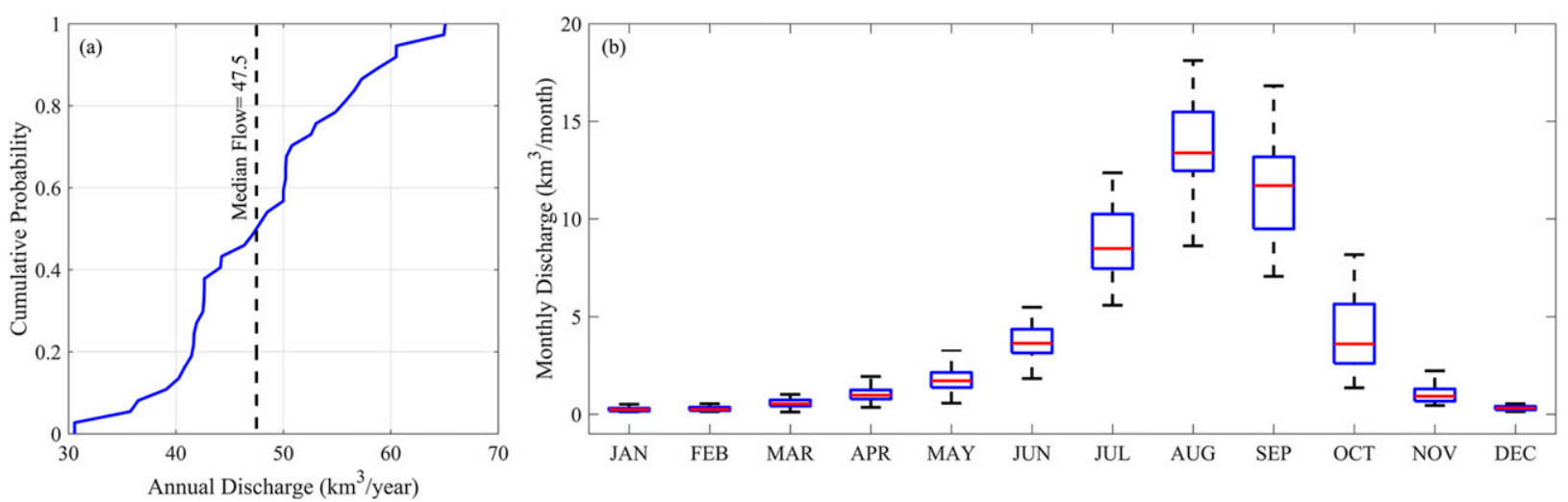

FIG. 10. (a) Cumulative probability of annual flow reaching Eldiem (inflow of GERD). (b) Monthly distribution of the monthly streamflow for the historical record (1981-2017). On each box, the central mark indicates the median depth, and the bottom and top edges of the box indicate the 25 th and 75 th percentiles (or interquartile range), respectively. The whiskers of the box extend to the most extreme data points not considered outliers.

residence time of Lake Nasser (large reservoir size compared to inflow) can increase the uncertainty in computed reservoir releases as the water balance approach assumes a plug flow reservoir.

While our primary objective is to build a satellitebased model that is capable of inferring the operation of reservoirs with more focus on large reservoirs (like HAD and GERD), one of the limitation of our current framework is the exclusion of the relatively smaller dams (e.g., Merowe Dam in Sudan with storage capacity of $12.5 \mathrm{~km}^{3}$ compared to 132 and $74 \mathrm{~km}^{3}$ for HAD and GERD, respectively). This limitation can be justified by such large difference in the storage capacity; however, if the reservoir model is to be applied in Sudan, for instance, including Merowe will be very important since it is the largest hydropower facility in Sudan and the storage at its reservoir impacts the upstream dams, for example, Sennar and Roseires (Satti et al. 2015). It is worth noting that the results of our study, that is, the performance the water balance model in simulating HAD outflow, are not impacted by the Merowe Dam (since its operation started in 2009 while our model validation is for the period 1998-2002). However, given the potential implications of our modeling framework to include the impacts of GERD on downstream countries, future studies are encouraged to employ the same water balance approach on other dams upstream of HAD to estimate the dam releases (in a similar manner as applied for HAD). For example, one can perform the water balance equation at Merowe Dam first to estimate reservoir outflow which can be then directed to HAD as monthly inflow (i.e., multireservoir water balance approach). Given such limitations in our modeling framework, further improvement of the simulation of HAD reservoir releases will require more accurate representation on other components of the water balance equation including: evaporation, water diversion to Toshka spillway, seepage (that is neglected in our formula), and other constraints or decisions that can be taken by the reservoir operators to meet downstream demands. Nonetheless, the overall performance of the reservoir modeling approach is considered adequate for water management to conduct a scenario assessment of the HAD operation under future challenges (e.g., GERD operation and climate change).

\section{d. HAD operation during dry versus wet episodes}

The HAD releases change during dry and wet episodes of discharges especially with the prevalence of extended droughts during the recent decades (MezeHausken 2004). The water balance approach at the HAD dam can provide more insights into how the HAD dam is operated under different climatic conditions. Figure 12 shows the use of the water balance approach based on satellite observations to derive the HAD operating curve during dry versus wet years. The dry and wet years are defined at Eldiem station by setting a threshold for the total discharge anomalies of the JJAS season for the full analysis period (1981-2017) (Fig. 12a). The threshold is set equal to half of the discharge anomaly standard deviation: any discharge anomaly above $3.64 \mathrm{~km}^{3}$ is considered as flooding condition (wet year), and any discharge anomaly below $3.64 \mathrm{~km}^{3}$ as drought condition (dry year). We then selected a three year episode of dry (and wet) conditions to understand how HAD was operated under such conditions. The dry and wet episodes selected are the years 2005-07 and 2011-13, respectively. Figure 12b shows the releases (averaged over the 3-yr episode) for each 

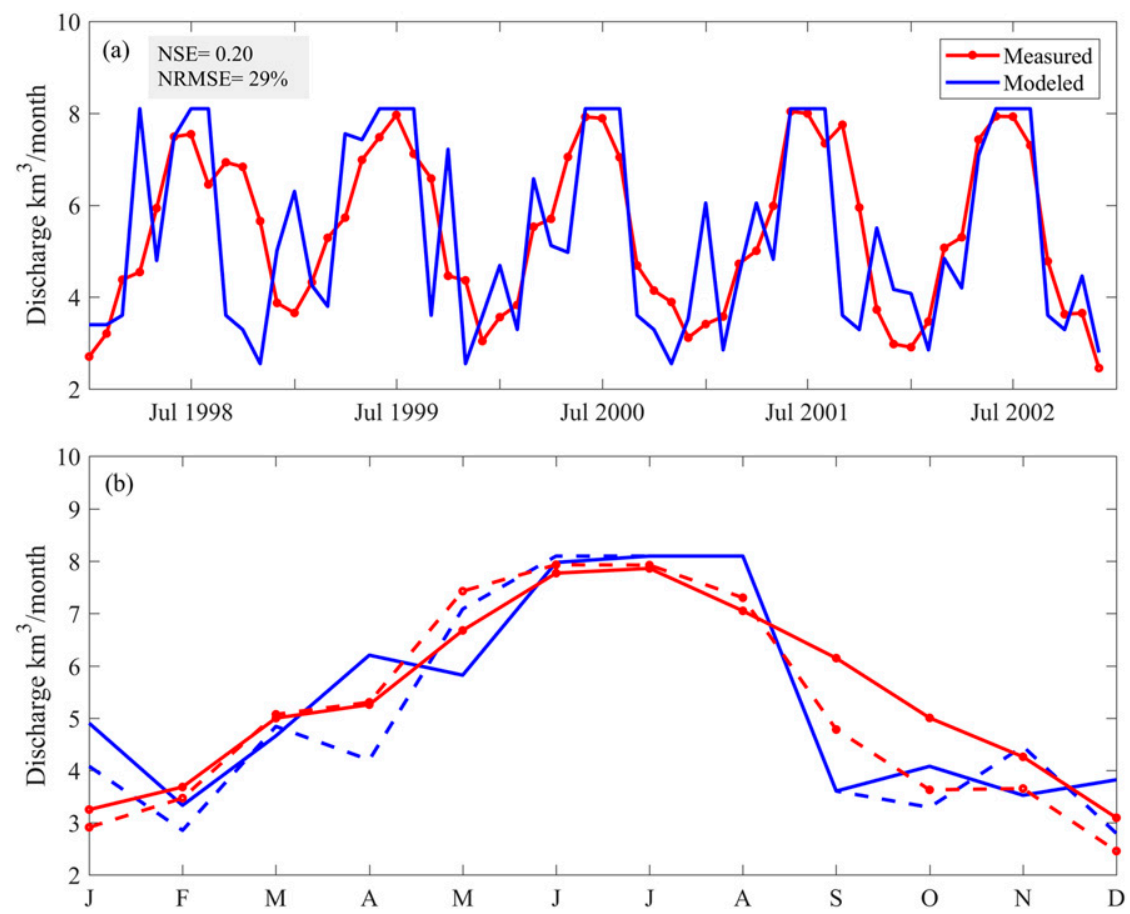

FIG. 11. (a) Monthly outflow and (b) derived operating curve for the HAD based on the water balance model and compared to measured discharge at HAD sluice gates [solid lines in (b) are monthly discharge averaged over the period 1998-2002 and dashed lines indicate monthly discharge for only 2002].

month of the dry (and wet) years using the water balance approach. As expected, lower discharge is released during dry conditions in most of the months (with exception of the spring season: March-May). A higher release during those months could be due to greater irrigation or water supply demand in the downstream dictated by a dry year. The largest difference between the releases in dry and wet years is noticed in August with $1.8 \mathrm{~km}^{3}$ month $^{-1}$ more discharge released in wet years. We expect that inferring reservoir operating patterns under such extreme climatic conditions will make it easier for Egypt to make decisions such as storing or spilling water to prepare for drought or flooding conditions exacerbated by GERD regulation.

The streamflow variability and hydrologic droughts and floods impact the agricultural sector land use. Figure 13 shows an example of how the agricultural area over the Nile Delta in Egypt changed during the period (1999-2017). The percentage of agricultural area is calculated using the annual normalized difference vegetation index (NDVI) generated from the near-infrared (NIR) and red (R) bands of Landsat-7 scenes. This percentage is calculated as the ratio between the number of pixels with NDVI greater than 0.50 and the total pixels in the delta region. The
NDVI greater than 0.5 is used as an indication of dense vegetation areas with the crops at peak growth stage (Jeevalakshmi et al. 2016). A significant shift in the agricultural area is noticed during two periods: period 1 considers the time between 2006 and 2010 that shows declining trend in the agricultural area, and period 2 between 2011 and 2014 when the agricultural area changed from $10 \%$ to more than $30 \%$. Such variation in the agricultural area can be attributed to the streamflow variability during dry (2006-10) versus wet years (2011-14). The different trends in the agricultural area for the two periods reflect the importance of considering the operation of dams under flow variability. Such variability

TABLE 4. Performance statistics for modeling the HAD releases using the water balance approach during the period (1998-2002).

\begin{tabular}{lcccr}
\hline \multicolumn{1}{c}{ Season $^{\mathrm{a}}$} & RBIAS & RMSE & NRMSE & NSE \\
\hline Winter (DJF) & $-20 \%$ & 1.20 & $36 \%$ & -5.40 \\
Spring (MAM) & $-1.5 \%$ & 1.40 & $25 \%$ & -1.53 \\
Summer (JJA) & $7 \%$ & 0.68 & $9 \%$ & -1.36 \\
Fall (SON) & $-27 \%$ & 2.40 & $47 \%$ & -2.28 \\
Overall & -1.4 & 1.56 & 28.64 & 0.20 \\
\hline
\end{tabular}

${ }^{\text {a }}$ Statistics are broken down by season (DJF, December-February; MAM, March-May; JJA, June-August; SON, SeptemberNovember). 

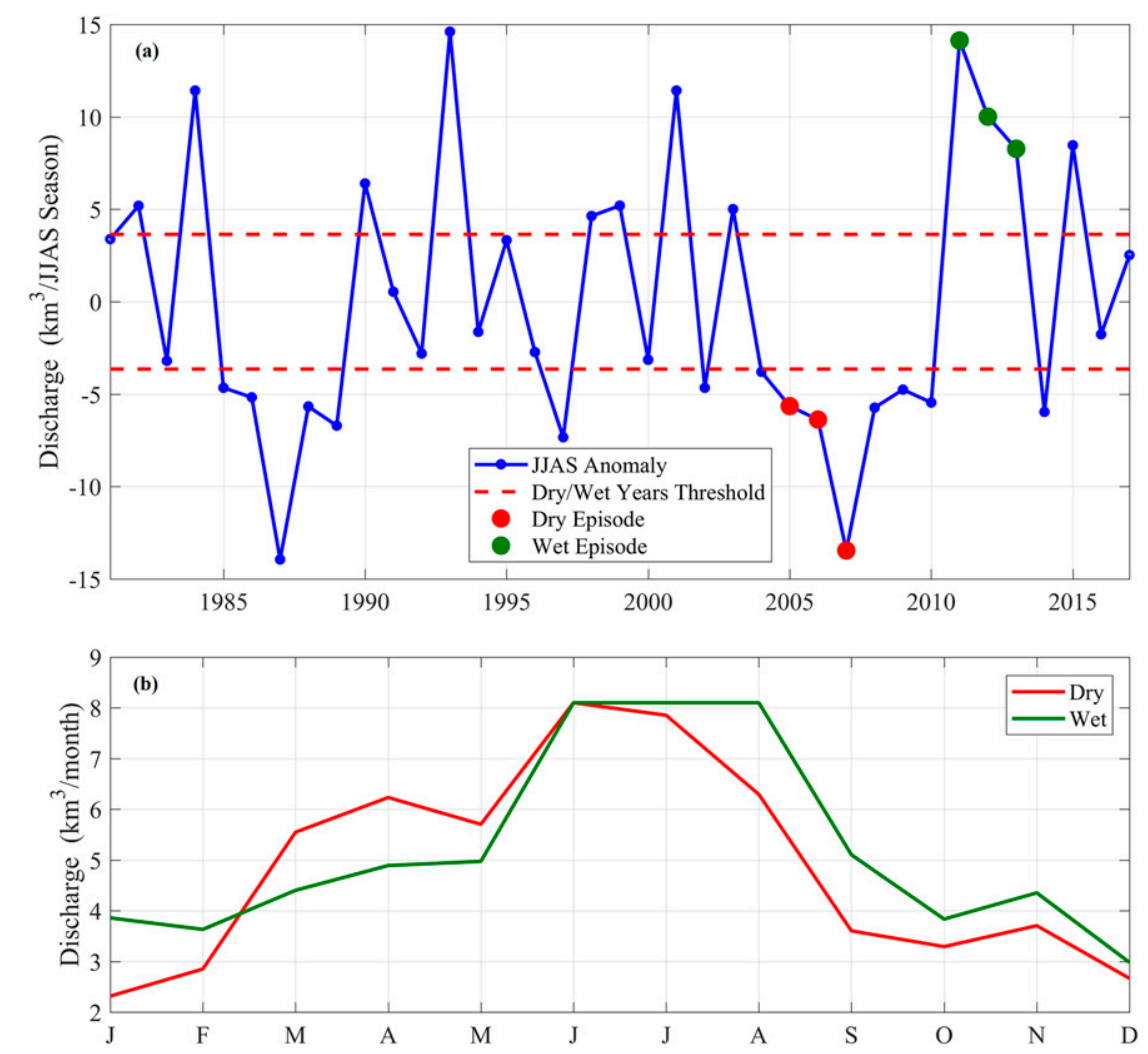

FIG. 12. (a) The discharge anomalies at Eldiem station averaged over the rainy season JJAS during the period 1981-2017; the red dashed line represents the threshold for the dry vs wet year identification at half of the standard deviation of the JJAS total discharge. (b) Operating curve of HAD for wet vs drought episodes using the water balance approach.

is notable in annual Nile River flows as reported in previous studies (Eltahir 1996; Siam and Eltahir 2017) and it is more likely to increase in future with climate change (Conway 2005). In addition to streamflow variability, changes in agricultural areas can also be associated with variations in nonclimatic factors, for example, development decisions, changes in government policies, and marginal changes in market conditions (Epule et al. 2018; Kassem et al. 2019). The impacts of nonclimatic factors are noticed when comparing the agricultural land use dynamics in some years where an increase (or decreases) in agricultural areas are not associated with wet (or dry) years [e.g., reduction in agricultural area from 2014 to 2015 (Fig. 13) corresponds to a wetter year in 2015 (Fig. 12)].

\section{Conclusions}

Our study presents the development of a modeling platform to predict the current and future reservoir operating rules in lower Nile River basin using satellite hydrometeorologic observations and macroscale hydrologic model. Our main findings are as follows:
1) The hydrological modeling of the BNB shows high accuracy in simulating streamflow along the BNB (validated at Khartoum and Eldiem stations). Such a modeling framework is a practical step to circumventing real-world data sharing issues in transboundary basins via the use of satellite observations.

2) The characterization of the streamflow climatology at Eldiem station lags rainfall by one month with peak discharge in August. The highest intra-annual variability of the streamflow is noticed in August and September. The ability of the VIC model to characterize the streamflow climatology upstream of the GERD is important for future assessment of GERD filling and operation scenarios and their impacts on HAD inflow. Understanding such impacts is also crucial to reevaluating the current operating rule for HAD to meet the downstream water demands in the context of emerging water management challenges.

3) Our results for the monthly HAD releases using satellite altimeter show good agreement with measured discharge downstream of the dam. The ability to estimate reservoir outflow using satellite remote 


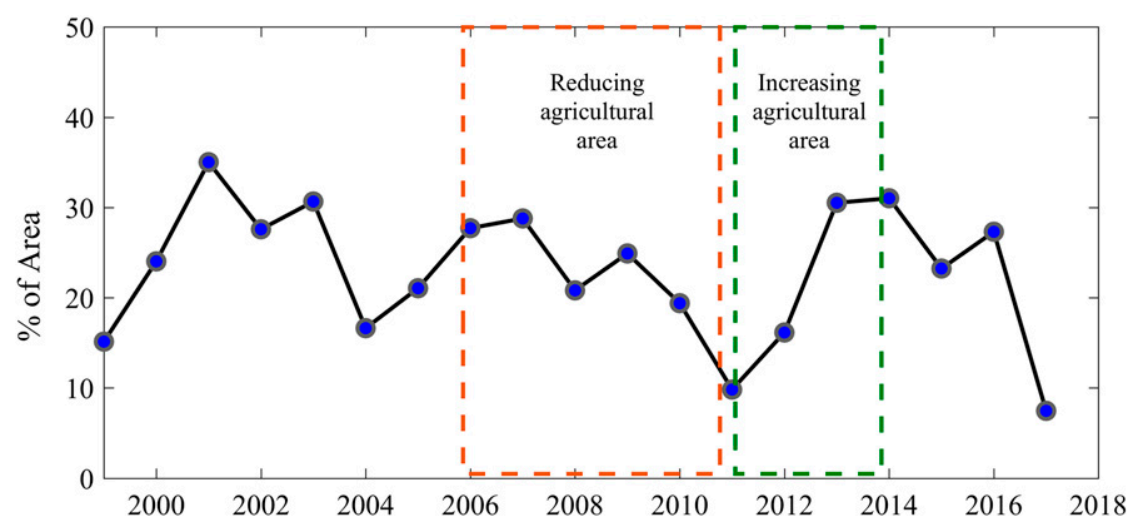

FIG. 13. Annual percentage of agricultural area in the Nile Delta region (calculated using NDVI greater than 0.50).

sensing has wide implications in transboundary water management. For instance, policy-makers can be supplied with better information of the HAD (and GERD) operations, which subsequently helps make more informed decisions about a wide array of water management issues.

The BNB modeling framework presented in our study has various implications in the management of water resources in the downstream countries of the Nile River. Building upon our model framework, long-term sustainability of the food-energy-water (FEW) security in the Eastern Nile basin can be explored in a nexus approach. Such a FEW nexus can highlight the interdependence of the three critical resources and therefore provide an effective way to control the releases from the basin dams. For example, any imposed changes to future flow reaching the HAD will impact the hydropower generated (energy domain) at the dam and the water released for irrigation in the Nile Delta (food domain). Such changes in the FEW system are more pronounced in the Eastern Nile basin due to increasing pressures on water resources from multiple stresses including human-induced land use changes and high population growth, rising demand for natural resources, and external factors such as climate change and variability (Al-Saidi et al. 2017).

Building a well-established satellite-based modeling framework for monitoring or predicting reservoir operations can benefit water managers and various stakeholders. For a country like Egypt, our developed framework can be operationalized in a decision support system (DSS) to monitor basin's transboundary reservoir operations, water storage, and release patterns by upstream riparian countries. Although the in situ data needed by such DSS systems are unavailable in the developing countries (Giupponi and Sgobbi 2013), especially in the case of transboundary basins, our framework shows the skill of satellite hydrometeorologic observations to drive hydrological modeling and infer the dam operation. Furthermore, the developed BNB model can benefit from the application of numerical weather prediction (NWP) forecast models, for example, NCEP Global Forecast System (GFS), to forecast short-term river flow. Flow forecasting is particularly important for adaptive management of water resources and development of reservoir regulation policies. The monitoring of upstream reservoirs and the prediction of impact on water availability downstream can help decision makers identify realistic measures to overcome water shortage problem in the short and long terms.

Acknowledgments. The first author was supported by a NASA Applied Sciences grant in Water Resources (NNX15AC63G). The second author was supported by the Surface Water Ocean Topography mission Science Team Grant (NNX16AQ54G).

\section{REFERENCES}

Abu-Zeid, M. A., and F. Z. El-Shibini, 1997: Egypt's high Aswan dam. Int. J. Water Resour. Dev., 13, 209-218, https://doi.org/ 10.1080/07900629749836.

Allam, M. N., and G. I. Allam, 2007: Water resources in Egypt: Future challenges and opportunities. Water Int., 32, 205-218, https://doi.org/10.1080/02508060708692201.

Allam, M. M., A. Jain Figueroa, D. B. McLaughlin, and E. A. Eltahir, 2016: Estimation of evaporation over the upper Blue Nile basin by combining observations from satellites and river flow gauges. Water Resour. Res., 52, 644-659, https://doi.org/ 10.1002/2015WR017251.

Al-Saidi, M., N. A. Elagib, L. Ribbe, T. Schellenberg, E. Roach, and D. Oezhan, 2017: Water-energy-food security nexus in the eastern Nile Basin: Assessing the potential of transboundary regional cooperation. Water-Energy-Food Nexus: Principles and Practices, Geophys. Monogr., Vol. 229, Amer. Geophys. Union, 103-116, https://doi.org/10.1002/9781119243175.ch10.

Alsdorf, D., C. Birkett, T. Dunne, J. Melack, and L. Hess, 2001: Water level changes in a large Amazon lake measured with 
spaceborne radar interferometry and altimetry. Geophys. Res. Lett., 28, 2671-2674, https://doi.org/10.1029/2001GL012962.

Awange, J. L., E. Forootan, M. Kuhn, J. Kusche, and B. Heck, 2014: Water storage changes and climate variability within the Nile Basin between 2002 and 2011. Adv. Water Resour., 73, 1-15, https://doi.org/10.1016/j.advwatres.2014.06.010.

Awulachew, S. B., F. D. Wubet, M. McCartney, and Y. S. Shiferaw, 2011: Hydrological water availability, trends and allocation in the Blue Nile Basin. Nile River Basin, Springer, 283-296, https://doi.org/10.1007/978-94-007-0689-7_14.

Balthrop, C., and F. Hossain, 2010: Short note: A review of state of the art on treaties in relation to management of transboundary flooding in international river basins and the global precipitation measurement mission. Water Policy, 12, 635, https:// doi.org/10.2166/wp.2009.117.

Bastawesy, M. A., F. I. Khalaf, and S. M. Arafat, 2008: The use of remote sensing and GIS for the estimation of water loss from Tushka lakes, southwestern desert, Egypt. J. Afr. Earth Sci., 52, 73-80, https://doi.org/10.1016/j.jafrearsci.2008.03.006.

Bayissa, Y., T. Tadesse, G. Demisse, and A. Shiferaw, 2017: Evaluation of satellite-based rainfall estimates and application to monitor meteorological drought for the Upper Blue Nile Basin, Ethiopia. Remote Sens., 9, 669, https://doi.org/10.3390/rs9070669.

Birkett, C. M., 1998: Contribution of the TOPEX NASA radar altimeter to the global monitoring of large rivers and wetlands. Water Resour. Res., 34, 1223-1239, https://doi.org/ 10.1029/98WR00124.

Block, P., and B. Rajagopalan, 2007: Interannual variability and ensemble forecast of Upper Blue Nile Basin Kiremt season precipitation. J. Hydrometeor., 8, 327-343, https://doi.org/ 10.1175/JHM580.1.

Bonnema, M., and F. Hossain, 2017: Inferring reservoir operating patterns across the Mekong Basin using only space observations. Water Resour. Res., 53, 3791-3810, https://doi.org/ 10.1002/2016WR019978.

_ - and _ 2019: Assessing the potential of the surface water and ocean topography mission for reservoir monitoring in the Mekong River Basin. Water Resour. Res., 55, 444-461, https:// doi.org/10.1029/2018WR023743.

_ - and Coauthors, 2016: Understanding satellite-based monthly-toseasonal reservoir outflow estimation as a function of hydrologic controls. Water Resour. Res., 52, 4095-4115, https://doi.org/ 10.1002/2015WR017830.

Calmant, S., F. Seyler, and J. F. Cretaux, 2008: Monitoring continental surface waters by satellite altimetry. Surv. Geophys., 29, 247-269, https://doi.org/10.1007/s10712-008-9051-1.

Chow, V. T., D. R. Maidment, and L. W. Mays, 1988: Atmospheric water. Applied Hydrology, McGraw-Hill, 53-98.

Conway, D., 2005: From headwater tributaries to international river: Observing and adapting to climate variability and change in the Nile basin. Global Environ. Change, 15, 99114, https://doi.org/10.1016/j.gloenvcha.2005.01.003.

Crétaux, J. F., and Coauthors, 2011: SOLS: A lake database to monitor in the Near Real Time water level and storage variations from remote sensing data. Adv. Space Res., 47, 14971507, https://doi.org/10.1016/j.asr.2011.01.004.

Dinku, T., S. Connor, and P. Ceccato, 2011: Evaluation of satellite rainfall estimates and gridded gauge products over the Upper Blue Nile region. Nile River Basin, Springer, 109-127, https:// doi.org/10.1007/978-94-007-0689-7_5.

Ebaid, H. M., and S. S. Ismail, 2010: Lake Nasser evaporation reduction study. J. Adv. Res., 1, 315-322, https://doi.org/10.1016/ j.jare.2010.09.002.
El-Shafie, A., M. R. Taha, and A. Noureldin, 2007: A neuro-fuzzy model for inflow forecasting of the Nile river at Aswan high dam. Water Resour. Manage., 21, 533-556, https://doi.org/ 10.1007/s11269-006-9027-1.

Elshamy, M., I. A. Seierstad, and A. Sorteberg, A., 2009: Impacts of climate change on Blue Nile flows using bias-corrected GCM scenarios. Hydrol. Earth Syst. Sci., 13, 551-565, https://doi.org/ 10.5194/hess-13-551-2009.

Eltahir, E. A., 1996: El Niño and the natural variability in the flow of the Nile River. Water Resour. Res., 32, 131-137, https:// doi.org/10.1029/95WR02968.

Enku, T., C. van der Tol, A. S. Gieske, and T. H. Rientjes, 2011: Evapotranspiration modeling using remote sensing and empirical models in the Fogera floodplain, Ethiopia. Nile River Basin, Springer, 163-178, https://doi.org/10.1007/978-94-007-0689-7_8.

Epule, T. E., J. D. Ford, S. Lwasa, B. Nabaasa, and A. Buyinza, 2018: The determinants of crop yields in Uganda: what is the role of climatic and non-climatic factors? Agric. Food Secur., 7, 10, https://doi.org/10.1186/s40066-018-0159-3.

FAO, 2016: AQUASTAT database: Irrigation and drainage. Accessed 29 October 2018, http://www.fao.org/nr/water/aquastat/ irrigationdrainage/index.stm.

Funk, C. C., and Coauthors, 2014: A quasi-global precipitation time series for drought monitoring. USGS Data Series 832, 4 pp., https://doi.org/10.3133/DS832.

— , and Coauthors, 2015: The climate hazards infrared precipitation with stations-A new environmental record for monitoring extremes. Sci. Data, 2, 150066, https://doi.org/10.1038/sdata.2015.66.

Gao, F., Y. Zhang, X. Ren, Y. Yao, Z. Hao, and W. Cai, 2018: Evaluation of CHIRPS and its application for drought monitoring over the Haihe River Basin, China. Nat. Hazards, 92, 155-172, https://doi.org/10.1007/s11069-018-3196-0.

Gebremichael, M., M. M. Bitew, F. A. Hirpa, and G. N. Tesfay, 2014: Accuracy of satellite rainfall estimates in the Blue Nile Basin: Lowland plain versus highland mountain. Water Resour. Res., 50, 8775-8790, https://doi.org/10.1002/2013WR014500.

Gerlak, A. K., J. Lautze, and M. Giordano, 2011: Water resources data and information exchange in transboundary water treaties. Int. Environ. Agreements Polit. Law Econ., 11, 179199, https://doi.org/10.1007/s10784-010-9144-4.

Giupponi, C., and A. Sgobbi, 2013: Decision support systems for water resources management in developing countries: Learning from experiences in Africa. Water, 5, 798-818, https://doi.org/10.3390/w5020798.

Habib, E., M. ElSaadani, and A. T. Haile, 2012: Climatologyfocused evaluation of CMORPH and TMPA satellite rainfall products over the Nile Basin. J. Appl. Meteor. Climatol., 51, 2105-2121, https://doi.org/10.1175/JAMC-D-11-0252.1.

Hossain, F., and N. Katiyar, 2006: Improving flood forecasting in international river basins. Eos, Trans. Amer. Geophys. Union, 87, 49-50, https://doi.org/10.1029/2006EO050001.

— — - Y. Hong, and A. Wolf, 2007: The emerging role of satellite rainfall data in improving the hydro-political situation of flood monitoring in the under-developed regions of the world. Nat. Hazards, 43, 199-210, https://doi.org/10.1007/ s11069-006-9094-x.

Iqbal, N., F. Hossain, H. Lee, and M. G. Akhtar, 2016: Satellite gravimetric estimation of groundwater storage variations over Indus basin in Pakistan. IEEE J. Sel. Top. Appl. Earth Obs. Remote Sens., 9, 3524-3534, https://doi.org/10.1109/ JSTARS.2016.2574378.

, ——, and M. G. Akhter, 2017: Integrated groundwater resource management using satellite gravimetry and physical 
modeling tools. Environ. Monit. Assess., 189, 128, https:// doi.org/10.1007/s10661-017-5846-1.

Jeevalakshmi, D., S. N. Reddy, and B. Manikiam, 2016: Land cover classification based on NDVI using LANDSAT8 time series: A case study Tirupati region. 2016 Int. Conf. on Communication and Signal Processing (ICCSP), Melmaruvathur, India, IEEE, 1332-1335, https://doi.org/10.1109/ICCSP.2016.7754369.

Kassem, H. S., A. R. S. Bello, B. M. Alotaibi, F. O. Aldosri, and G. S. Straquadine, 2019: Climate change adaptation in the Delta Nile region of Egypt: Implications for agricultural extension. Sustainability, 11, 685, https://doi.org/10.3390/ su11030685.

Keys, T. A., and D. T. Scott, 2018: Monitoring volumetric fluctuations in tropical lakes and reservoirs using satellite remote sensing. Lake Reservoir Manage., 34, 154-166, https://doi.org/ 10.1080/10402381.2017.1402226.

King, A., and P. Block, 2014: An assessment of reservoir filling policies for the Grand Ethiopian Renaissance Dam. J. Water Climate Change, 5, 233-243, https://doi.org/10.2166/wcc.2014.043.

Lehner, B., and Coauthors, 2011: High-resolution mapping of the world's reservoirs and dams for sustainable river-flow management. Front. Ecol. Environ., 9, 494-502, https://doi.org/ $10.1890 / 100125$.

Liang, X., and J. Guo, 2003: Intercomparison of land-surface parameterization schemes: sensitivity of surface energy and water fluxes to model parameters. J. Hydrol., 279, 182-209, https://doi.org/10.1016/S0022-1694(03)00168-9.

, D. P. Lettenmaier, E. F. Wood, and S. J. Burges, 1994: A simple hydrologically based model of land surface water and energy fluxes for general circulation models. J. Geophys. Res., 99, 14 415-14 428, https://doi.org/10.1029/94JD00483.

— moisture parameterization of the VIC-2L model: Evaluation and modification. Global Planet. Change, 13, 195-206, https:// doi.org/10.1016/0921-8181(95)00046-1.

Lohmann, D., E. Raschke, B. Nijssen, and D. P. Lettenmaier, 1998: Regional scale hydrology: I. Formulation of the VIC-2L model coupled to a routing model. Hydrol. Sci. J., 43, 131141, https://doi.org/10.1080/02626669809492107.

Longuevergne, L., C. Wilson, B. R. Scanlon, and J. F. Crétaux, 2013: GRACE water storage estimates for the Middle East and other regions with significant reservoir and lake storage. Hydrol. Earth Syst. Sci. 17, 4817-4830, https://doi.org/10.5194/hess-17-4817-2013.

Loveland, T. R., B. C. Reed, J. F. Brown, D. O. Ohlen, Z. Zhu, L. W. Yang, and J. W. Merchant, 2000: Development of a global land cover characteristics database and IGBP DISCover from $1 \mathrm{~km}$ AVHRR data. Int. J. Remote Sens., 21, 1303-1330, https://doi.org/10.1080/014311600210191.

Maurer, E. P., A. W. Wood, J. C. Adam, D. P. Lettenmaier, and B. Nijssen, 2002: A long-term hydrologically based dataset of land surface fluxes and states for the conterminous United States. J. Climate, 15, 3237-3251, https://doi.org/10.1175/15200442(2002)015<3237:ALTHBD>2.0.CO;2.

Melesse, A. M., W. Abtew, S. G. Setegn, and T. Dessalegne, 2011: Hydrological variability and climate of the Upper Blue Nile River basin. Nile River Basin, Springer, 3-37, https://doi.org/ 10.1007/978-94-007-0689-7_1.

Meze-Hausken, E., 2004: Contrasting climate variability and meteorological drought with perceived drought and climate change in northern Ethiopia. Climate Res., 27, 19-31, https:// doi.org/10.3354/cr027019.

Moriasi, D. N., J. G. Arnold, M. W. Van Liew, R. L. Bingner, R. D. Harmel, and T. L. Veith, 2007: Model evaluation guidelines for systematic quantification of accuracy in watershed simulations. Trans. ASABE, 50, 885-900, https://doi.org/10.13031/2013.23153.

Muala, E., Y. A. Mohamed, Z. Duan, and P. van der Zaag, 2014: Estimation of reservoir discharges from Lake Nasser and Roseires Reservoir in the Nile Basin using satellite altimetry and imagery data. Remote Sens., 6, 7522-7545, https://doi.org/ 10.3390/rs6087522.

Mulat, A. G., and S. A. Moges, 2014: Assessment of the impact of the Grand Ethiopian Renaissance Dam on the performance of the High Aswan Dam. J. Water Resource Prot., 6, 583, https:// doi.org/10.4236/jwarp.2014.66057.

Nachtergaele, F. O., 1999: From the Soil Map of the World to the Digital Global Soil and Terrain Database: 1960-2002. Handbook of Soil Science, CRC Press, 5-17.

Nijssen, B., G. M. O’Donnell, D. P. Lettenmaier, D. Lohmann, and E. F. Wood, 2001: Predicting the discharge of global rivers. J. Climate, 14, 3307-3323, https://doi.org/10.1175/1520-0442(2001) 014<3307:PTDOGR>2.0.CO;2.

Omar, M. E. D. M., and A. M. Moussa, 2016: Water management in Egypt for facing the future challenges. J. Adv. Res., 7, 403-412, https://doi.org/10.1016/j.jare.2016.02.005.

Paredes-Trejo, F. J., H. A. Barbosa, and T. L. Kumar, 2017: Validating CHIRPS-based satellite precipitation estimates in Northeast Brazil. J. Arid Environ., 139, 26-40, https://doi.org/ 10.1016/j.jaridenv.2016.12.009.

Plengsaeng, B., U. Wehn, and P. van der Zaag, 2014: Data-sharing bottlenecks in transboundary integrated water resources management: a case study of the Mekong River Commission's procedures for data sharing in the Thai context. Water Int., 39, 933-951, https://doi.org/10.1080/02508060.2015.981783.

Rientjes, T. H., A. T. Haile, A. S. Gieske, B. H. Maathuis, and E. Habib, 2011: Satellite based cloud detection and rainfall estimation in the upper Blue Nile basin. Nile River Basin, Springer, 93-107, https://doi.org/10.1007/978-94-007-0689-7_4.

Satti, S., B. Zaitchik, and S. Siddiqui, 2015: The question of Sudan: A hydro-economic optimization model for the Sudanese Blue Nile. Hydrol. Earth Syst. Sci., 19, 2275-2293, https://doi.org/ 10.5194/hess-19-2275-2015.

Shahin, M. M., 1985: Hydrology of the Nile Basin. Developments in Water Science, Vol. 21, Elsevier, 575 pp.

Siam, M. S., and E. A. Eltahir, 2017: Climate change enhances interannual variability of the Nile river flow. Nat. Climate Change, 7, 350-354, https://doi.org/10.1038/nclimate3273.

Siddique-E-Akbor, A. H., F. Hossain, S. Sikder, C.K. Shum, S. Tseng, Y. Yi, F.J. Turk, and A. Limaye, 2014: Satellite precipitation data-driven hydrological modeling for water resources management in the Ganges, Brahmaputra, and Meghna Basins. Earth Interact., 18, https://doi.org/10.1175/EI-D-14-0017.1.

Sutcliffe, J. V., and Y. P. Parks, 1999: The Hydrology of the Nile. IAHS Spec. Publ. 5, International Association of Hydrological Sciences, $180 \mathrm{pp}$.

Taye, M. T., P. Willems, and P. Block, 2015: Implications of climate change on hydrological extremes in the Blue Nile basin: A review. J. Hydrol. Reg. Stud., 4, 280-293, https://doi.org/ 10.1016/j.ejrh.2015.07.001.

—, T. Tadesse, G. B. Senay, and P. Block, 2016: The Grand Ethiopian Renaissance Dam: Source of cooperation or contention? J. Water Resour. Plann. Manage., 142, 02516001, https://doi.org/10.1061/(ASCE)WR.1943-5452.0000708.

Teferi, E., S. Uhlenbrook, and W. Bewket, 2015: Inter-annual and seasonal trends of vegetation condition in the Upper Blue Nile (Abay) Basin: Dual-scale time series analysis. Earth Syst. Dyn., 6, 617-636, https://doi.org/10.5194/esd-6-617-2015. 
van der Krogt, W., and H. Ogink, 2013: Development of the eastern Nile water simulation model. Rep. 1206020-000-VEB-0010, Eastern Nile Technical Regional Office, 33 pp., https:// entrospace.nilebasin.org/handle/20.500.12351/83.

Wang, X., Y. Chen, L. Song, X. Chen, H. Xie, and L. Liu, 2013: Analysis of lengths, water areas and volumes of the Three Gorges Reservoir at different water levels using Landsat images and SRTM DEM data. Quat. Int., 304, 115-125, https:// doi.org/10.1016/j.quaint.2013.03.041.

Waterbury, J., 2008: The Nile Basin: National Determinants of Collective Action. Yale University Press, $211 \mathrm{pp}$.

Wheeler, K., and S. Setzer, 2012: Eastern Nile RiverWare planning model. Final Rep., Eastern Nile Technical and Regional Office, 150 pp., https://entrospace.nilebasin.org/ handle/20.500.12351/85.

Wulder, M. A., J. G. Masek, W. B. Cohen, T. R. Loveland, and C. E. Woodcock, 2012: Opening the archive: How free data has enabled the science and monitoring promise of Landsat. Remote Sens. Environ., 122, 2-10, https://doi.org/10.1016/ j.rse.2012.01.010
Yihdego, Y., A. Khalil, and H. S. Salem, 2017: Nile River's basin dispute: Perspectives of the Grand Ethiopian Renaissance Dam (GERD). Global J. Hum.-Soc. Sci., 17B, 1-21.

Zarfl, C., A. E. Lumsdon, J. Berlekamp, L. Tydecks, and K. Tockner, 2015: A global boom in hydropower dam construction. Aquat. Sci., 77, 161-170, https://doi.org/10.1007/ s00027-014-0377-0.

Zaroug, M. A., E. A. Eltahir, and F. Giorgi, 2014: Droughts and floods over the upper catchment of the Blue Nile and their connections to the timing of El Niño and La Niña events. Hydrol. Earth Syst. Sci., 18, 1239-1249, https://doi.org/10.5194/ hess-18-1239-2014.

Zhang, Y., P. Block, M. Hammond, and A. King, 2015: Ethiopia's Grand Renaissance Dam: Implications for downstream riparian countries. J. Water Resour. Plann. Manage., 141, 05015002, https:// doi.org/10.1061/(ASCE)WR.1943-5452.0000520.

Zhu, C., and D. P. Lettenmaier, 2007: Long-term climate and derived surface hydrology and energy flux data for Mexico: 1925-2004. J. Climate, 20, 1936-1946, https://doi.org/10.1175/ JCLI4086.1. 